\title{
VACCINE-ASSOCIATED PARALYTIC POLIOMYELITIS: A CASE REPORT OF DOMICILIARY TRANSMISSION
}

José A. Paz, Marcelo G. Vallada, Silvia N. C. H. Marques, Erasmo B. Casella, Heloisa H. S. Marques and Maria J. Marques-Dias

RHCFAP/3011

PAZ J A et al. - Vaccine-associated paralytic poliomyelitis: a case report of domiciliary transmission. Rev. Hosp. Clín. Fac. Med. S. Paulo 55(3):101-104, 2000.

SUMMARY: Poliomyelitis associated with live strain vaccine is defined as the paralytic form of the acute anterior poliomyelitis related to the vaccine strain. Since these strains behave similarly to the wild-type virus, we can differentiate, epidemiologically, two types of vaccine-associated poliomyelitis: cases in which the patient was vaccinated and cases in which the patient had had contact with vaccinated individuals. We herein present the case of an unvaccinated child, with a clinical picture of an acute anterior poliomyelitis associated with the live strain vaccine, whose brother received the Sabin vaccine 20 days before the onset of the symptoms. Vaccine strain of the type 3 poliovirus was isolated in fecal culture and a presented mutation in nucleotide $472(\mathrm{C} \rightarrow \mathrm{U})$ in the 5 ' non-coding region, which is strongly related to the higher strain virulence.

DESCRIPTORS: Poliomyelitis. Vaccine-associated poliomyelitis. Domiciliary transmission.

Live strain vaccine-associated poliomyelitis (VAP) is defined as the paralytic form of the acute anterior poliomyelitis related to the vaccine strain (VS). Since VS acts similarly to the wild-type virus (WS) with intestinal replication and fecal elimination, it is possible to differentiate epidemiologically two types of VAP: a) cases where the patient was vaccinated and b) cases where the patient has had contact with vaccinated individuals. The average interval between vaccination and development of symptoms is 31 days and an accurate diagnosis requires isolation of VS through culture and identification by polymerase chain reaction (PCR).

Polioviruses are enteroviruses from the Picornaviridae family that have an icosahedral particle formed by 60 copies of each of the four proteic capsids, VP1 to VP4, and a RNA genome with approximately 7500 nucleotides ${ }^{1}$. According to the capsid antigenicity, it is possible to identify three polioviruses serotypes designated as: 1, 2, and 3 .

The three VS strains (Sabin strains 1, 2, and 3) differ from the WS by mutations in nucleotide 472 in the 5' noncoding region and in nucleotide 2034, which reduce virus replication in the human intestine and cause changes in the structural protein amino acids affecting viral replication at high temperatures. VS presents mutation reversion 72 hours after vaccine administration ${ }^{2,3,4}$. All three VS strains may revert to WS; however, Sabin strain 1 is very safe and rarely associated with VAP; VS-2 is safe for vaccinated individuals, but may be responsible for some cases of paralysis in contacts, and VS-3 is the most genetically unstable

From the Department of Pediatrics, Hospital das Clínicas, Faculty of Medicine, University of São Paulo. and it is accountable for the majority of VAP cases.

The estimated VAP frequency in the United States (US) is 1 case in 2 400000 doses in vaccinated patients ${ }^{5}$, similar to what was estimated in Latin America during the period 1989-1991 (1 case in 1500000 to 2200000 doses) ${ }^{6}$. The risk is higher after the first dose, 1 in 500000 doses in recipients, and 1 in 760000 doses, among those persons who had had contact with vaccinees ${ }^{5,7}$ and declines substantially in the subsequent doses. In Brazil the frequency in this risk has been estimated as 1 case in 4400000 to 6 700000 doses in all children vaccinated and as 1 in 6700 000-15 500 000 doses in communicants. In firsttime vaccinees, the risk was 10 to 15 times higher. For immunocompetent patients who developed VAP, there is no contraindication for receiving the subsequent doses. Immunodeficient in- 
dividuals have a higher estimated risk of developing VAP (3 200-6 800 times higher) ${ }^{8} ; 18 \%$ of the cases were described in this group, especially in children with hypogammaglobulinemia or agammaglobulinemia. In the US, among 125 reported cases, 49 (39\%) occurred in immunocompetent recipients, $78 \%$ of them in the first dose, 93\% during the first year of life; and 40 (32\%) occurred in immunocompetent contacts and $24 \%$ in immunodeficient vaccinees or contacts ${ }^{7}$. For the latter groups, it is recommended that immunization be done with the inactivated vaccine ${ }^{9,10}$.

Healthy unvaccinated adults and children infected with human immunodeficiency virus (HIV) also are groups with a higher risk for VAP. Two VAP cases were described in children $\mathrm{HIV}+{ }^{11,12}$, but as since benefits of vaccination outweigh the risk of infection by the wild poliomyelitis virus, the World Health Organization still recommends the use of live strain vaccine for these patients in developing countries ${ }^{13}$.

We describe a case of VAP, aiming to alert pediatricians and neurologists to the possibility of diagnosing poliomyelitis associated with the vaccine, even in infants who have not received the vaccine but have had contact with vaccinees, as well as about the necessary procedures for obtaining the definitive diagnosis.

\section{CASE REPORT}

A white, 6-month-old male from Osasco, São Paulo, was admitted with a prodromic picture of fever and irritability for the previous 12 days, followed by a generalized weakness. The patient had an incorrect vaccination schedule and, due to maternal neglect, did not receive the Sabin vaccine. However, he had contact with his 4year-old brother who was vaccinated during a vaccine campaign (lot S.1957-
A1A, Smith Kline) 20 days before the onset of the clinical picture. No further cases of adverse events were reported in other children vaccinated with this lot, according to the São Paulo State Immunization Program.

With regard to his personal and family history, no reference has been made to recent use of intramuscularroute medications, repetitive infections, or immunodeficiency. The patient received only BCG and a single dose of DPT vaccines at 4 months of age.

The first clinical examination showed a poor appearance, fever, and tachypnea and the neurological examination revealed a flaccid and areflexic tetraplegia without meningeal signs. The patient developed respiratory failure associated with autonomic disturbances (sweating and arterial hypertension) 12 hours after hospitalization. Subsequently, the respiratory pattern improved and mechanical ventilation was suspended; nevertheless, the flaccid tetraplegia remained and, almost a month later, the first symptoms of thoracic and limb muscular atrophy appeared.

Initial cerebrospinal fluid (CSF) exam showed cytological protein dissociation; this evolved with a cellularity reduction and a moderate increase of protein levels (Table 1).

Electroneuromyographic examination disclosed signs of severe, asym- metric, and exclusive motor axonal degeneration affecting all limbs, with no signs of demyelination, a typical pattern of anterior horn cell disease. The levels of immunoglobulins (IgG, IgM, $\operatorname{IgA}$ and $\operatorname{IgG}$ subclasses) were normal, and HIV serologic test was negative.

Poliovirus 3 serologic titres indicated a significant increase between the two samples collected (Table 2). In the faecal culture in animal and humanorigin cells (Hep-2C and RD) carried out at the Instituto Adolfo Lutz of São Paulo, a virus was isolated, and its serotyping by neutralizing tests with a specific equine and hyperimmune serum indicated the presence of a poliovirus 3 . The final identification of the virus was obtained through hybridization techniques made with genotypic catheter and PCR analysis, and revealed mutation in nucleotide 472 $(\mathrm{C} \rightarrow \mathrm{U})$ in the 5 ' non-coding region which defined this as a vaccine strain.

\section{COMMENTS}

The oral poliomyelitis virus vaccine, which is composed of live attenuated poliovirus (Sabin vaccine), is still the vaccine chosen in countries like Brazil due to the advantages of this vaccine over the injectable one using inactivated virus (Salk vaccine). Some of the advantages are: the possibility of

Table 1 - Characteristics of the cerebrospinal fluid

\begin{tabular}{lccc}
\hline & \multicolumn{3}{c}{ Days after admission } \\
\cline { 2 - 4 } & 0 & 1 & 5 \\
\cline { 2 - 4 } & & Days after the onset of symptoms \\
\cline { 2 - 4 } & 12 & 13 & 18 \\
\hline Data & & & \\
Erythrocyte/ $\mathrm{mm}^{3}$ & 04 & 43 & 48 \\
Cells/ $\mathrm{mm}^{3}$ & 66 & 03 & $93 \%$ \\
Lymphocytes & $67 \%$ & - & $03 \%$ \\
Reticular monocytes & $31 \%$ & - & $04 \%$ \\
Neutrophils & $01 \%$ & - & 141 \\
Protein (mg/dl) & 20 & 50 & 102 \\
Glucose (mg/dl) & 45 & 76 & 666 \\
Chlorate (mg/dl) & - & & \\
\hline
\end{tabular}


Table 2 - Poliovirus serologic study (ELISA) in 2 samples.

\begin{tabular}{ccc}
\hline Serologic reaction & at admission & 21 days after admission \\
\hline Poliovirus 1 & $1: 32$ & $1: 64$ \\
Poliovirus 2 & $<1: 8$ & $1: 16$ \\
Poliovirus 3 & $1: 128$ & $>1: 1024$ \\
\hline
\end{tabular}

VS disseminating among the population, conferring protection to unvaccinated people, easy administration, and low $\cos ^{14,15}$.

In the US, eight cases of VAP per year are estimated to occur; $76-88 \%$ occur after the first and second doses of the vaccine ${ }^{10}$. In Brazil, the exact number of confirmed VAP cases is unknown ${ }^{6}$. Immunological disturbances (mainly, combined immunodeficiency and hypogammaglobulinemia or agammaglobulinemia), first vaccinal dose, and contact between non-vaccinated and newly-vaccinated individuals are considered as conditions of higher risk for VAP, as was the case herein described on which the delay in taking the first dose means a higher risk for VAP. After the second month of life, maternal antibodies are at very low or absent levels, facilitating an increased dissemination of the vaccinal virus ${ }^{16}$. Similar to poliomyelitis caused by the wild virus, intramuscular injections during viral incubation period are also considered as a risk factor for $\mathrm{VAP}^{15}$.

VAP clinical symptoms are likely the same as those of the poliomyelitis caused by VS, including respiratory failure due to paralysis of the diaphragm and intercostal musculature such as what occurred with the patient under discussion, who had what is considered a severe form. Usually sensory symptoms are absent, but radicular and meningeal compromising signs may be disappearing when motor deficit improves and atrophies emerge. The hypotonia and the reduction or absence of reflexes are quite clear. The clinical picture begins between 4 and 40 days after the patient is vaccinated, and motor sequelae compatible with poliomy- elitis occur 60 days after the onset of the deficit ${ }^{17}$. In cases of contacts, the flaccid paralysis arises between 4 and 85 days after vaccination, with transmission occurring by direct contact or oral-fecal route.

This patient's CSF pointed to the classic pattern of cito-proteic dissociation evolving to a moderate protein increase, as has been classically attributed to acute poliomyelitis; electroneuromyographic examination carried out at the sequel phase pointed to anterior horn cell disease.

Etiological diagnosis of poliomyelitis was confirmed based on serologic study of two samples obtained in the acute and convalescent phase, respectively, that showed a more than 4-fold increase in the type 3 titre, indicating recent infection.

In order to confirm the diagnosis of VAP, the isolation of vaccinal poliovirus in faeces culture from two samples collected during the first 14 days after the establishment of the motor deficit is essential. As vaccinal enteroviruses may still be eliminated through the feces for up to two months after contact, even in samples collected 15-40 days after onset of symptoms, CV isolation confirms diagnosis of VAP. Virus isolation in CSF is an exception ${ }^{18}$. In VAP cases, type setting and characterization (wild or vaccinal) through molecular hybridization and PCR, as well as nucleotide sequencing, are important to clearly define the responsibility of the attenuated virus in the clinical picture and to a better understanding of the poliovirus biology, and to eliminate or reduce adverse effects associated with the Sabin vaccine ${ }^{15}$.

In our country, Friedreich and colleagues described 8 cases of VAP with isolation of type $3 \mathrm{VS}$ during 1990-1992; four of these patients were under 1 year of age, and in 3 of them the clinical picture developed after the first dose ${ }^{2,19}$.

In 1995, after successful mass immunization campaigns with the live strain vaccine and the important efforts undertaken by the epidemiological surveillance from 1980 to 1994 , the autochthonous transmission of the wild poliovirus was considered eradicated in Brazil and in the Americas.

Since then, controversies on eventual changes in the vaccination program have been the subject of intensive discussion in countries where the wild poliomyelitis was brought under control. In some European countries and in the US, it is suggested that the first doses should be made with the inactivated virus vaccine, followed by a schedule of vaccines with attenuated virus. Theoretically, this change in the immunization calendar would prevent 50 to $70 \%$ of VAP cases ${ }^{7,14,20}$, mainly in patients who are immunocompetent; nonetheless, it would not completely protect immunodeficient patients against VAP, for whom it is also recommended that household members avoid attenuated virus vaccination.

In Brazil, changes in the immunization program against poliomyelitis are not yet discussed due to increase in costs, low compliance to the intramuscular vaccine, precarious sanitary conditions, and the fact that VS persistence in other regions worldwide would facilitate reintroduction and dissemination of the poliovirus all over the country.

It is important to remember that young people under 15 years of age presenting a sudden flaccid motor deficit, regardless of the assumption of a polio diagnosis, should be reported to the epidemiological surveillance system and investigated through fecal collection to isolate the poliovirus and verify the diagnosis of poliomyelitis. 
PAZ J A e col. - Poliomielite associada à vacina: descrição de caso por transmissão domiciliar. Rev. Hosp. Clín Fac. Med. S. Paulo 55(3):101-104, 2000.

A poliomielite associada à vacina oral é definida como a forma paralítica da poliomielite anterior aguda decorrente da cepa vacinal. Uma vez que o comportamento da cepa vacinal é semelhante ao do vírus selvagem, epidemiologicamente podemos distinguir dois tipos de poliomielite associada à vacina, os casos em que o paciente foi vacinado e os casos em que o paciente teve contato com pessoas que receberam a vacina. Apresentamos o caso de um lactente não vacinado, que apresentou quadro de poliomielite anterior aguda associada à vacina oral, cujo irmão havia recebido a vacina Sabin 20 dias antes do início do qua- dro clínico. Na cultura de fezes do paciente foi isolado o poliovírus tipo 3 , cepa vacinal, que apresentava mutação do nucleotídeo $472(\mathrm{C} \rightarrow \mathrm{U})$ na região 5 ' não codificadora, a qual está significativamente relacionada com a maior virulência da cepa.

DESCRITORES: Poliomielite. Poliomielite pós-vacinal. Transmissão domiciliar.

\section{REFERENCES}

1. MINOR PD, MACADAM AJ, STONE DM et al. - Genetic basis of attenuation of the Sabin live poliovirus vaccines. Biologicals 1993;21:357-363.

2. FRIEDREICH F, FILIPPIS AMB, FERREIRA FC et al. - Genoma characterization of type 3 polioviruses isolated from vaccineassociated poliomyelitis cases in Brazil. Braz J Med Biol Res 1995; 28:195-200.

3. BEALE AJ - Efficacy and safety of live poliovirus vaccine and inactivated poliovirus vaccine. Pediatr Infect Dis J 1991;10:970972.

4. BEALEAJ - Polio vaccines: time for a change in immunisation policy? Lancet 1990;335:839-842.

5. JOHNSON D - US changes polio vaccination programme. BMJ 1997;314 (7079):465.

6. ANDRUS JK, STREBEL PM, QUADROS CA et al. - Risk of vaccineassociated paralytic poliomyelitis in Latin America, 1989-91. WHO Bull 1995; 73(1):33-40.

7. COMMITTEE on infectious diseases - Poliomyelitis prevention: recommendations for use of inactivated poliovirus vaccine and live poliovirus vaccine. Pediatrics 1997;99(2):300-305.

8. SUTTER RW \& PREVOTS DR - Vaccine-associated paralytic poliomyelitis among immunodeficient persons. Infect Med 1994;426:429-30.

9. NIKOWANE BM, WASSILAK SGF, ORENSTEIN WA et al. - Vaccineassociated paralytic poliomyelitis: 1973 through 1984. JAMA 1987;257:1335-40.

10.STREBEL PM, SUTTER RW, COCHI SL et al. - Epidemiology of poliomyelitis in the United States one decade after the last reported case of indigenous wild virus-associated disease. Clin Infect Dis 1992;14:568-79.
11. INAM CHITSIKE \& RALPH VAN FURTH - Paralytic poliomyelitis associated with live poliomyelitis vaccine in child with HIV infection in Zimbabwe: case report. BMJ 1999;318 fs28:841-3.

12. ION-NEDELIU N, DOBRESCU A, STREBEL FM et al. - Vaccineassociated paralytic poliomyelitis and HIV infection. Lancet 1994;343:51-2.

13. VERNON A, OKWO B, LUBAMBA N et al. - Paralytic poliomyelitis and HIV infection in Kinshasa, Zaire. In: INTERNATIONAL CONFERENCE ON AIDS, $6^{\text {th }}$, San Francisco, CA. 1992. v.2 (abstr 2005).

14. MURDIN AD, BARRETO L \& PLOTKIN S - Inactivated poliovirus vaccine: past and present experience. Vaccine 1996;14(8):735-746.

15. STREBEL PM, LON-NEDELAU N, BAUGHMAN AL et al. Intramuscular injections and vaccine-associated paralytic poliomyelitis. N Engl J Med 1995;332(8):500-6.

16. WRIGHT PF \& KARZON DT - Minimizing the risks associated with the prevention of poliomyelitis. New Engl J Med 1995;332(8):529530.

17. SEPKOWITZ S - Intramuscular injections and vaccine-associated poliomyelitis. N Engl J Med 1995;333(1):62.

18. BRAZIL, Ministério da Saúde - Manual de vigilância epidemiológica dos eventos adversos pós-vacinação. FUNASA, Brasilia, 1998. p. $45-47$.

19. FRIEDRICH F - Rare adverse events associated with poliovirus vaccine in Brazil. Braz J Med Biol Res 1997;30:(6):695-703.

20. KOHBERGER R, SUTTER R \& RHODES P - Modeling the five immunization scheduled options. In: Presented at Institute of Medicine, Polio Workshop. Washington DC, June 1995.

Received for publication on the 10/05/00 